\title{
MUTU GIZI ANEKA KUDAPAN COKIBUS
}

\author{
Thresia Dewi Kartini $B^{\bowtie}$, Nadimin \\ Jurusan Gizi Poltekkes Kemenkes Makassar
}

\section{ARTICLE INFO \\ Article history}

Submitted : 2021-09-30

Revised : 2021-10-29

Accepted : 2021-12-29

Keywords:
Cokibus
Snacks
Nutritional quality

\section{Kata Kunci: \\ Cokibus \\ Kudapan \\ Mutu gizi}

\begin{abstract}
Snacks are small meals usually served with drinks, both for daily use and for special occasions. Cokibus snack is a snack that is made to complement the intake of nutrients, especially for children who experience stunting. Makassar City has more malnourished children than other cities/districts, namely $22.1 \%$ underweight, $25.2 \%$ stunting, and $9.4 \%$ wasting. This study aims to determine changes in nutritional quality, namely the levels of macronutrients, iron, and calcium in various Cokibus snacks. This type of research is laboratory research. The sample consisted of 4 kinds of snacks, 1 type of Cokibus consisting of standard, and one substitution treatment of $10 \%$ snakehead fish meal. Each sample was repeated twice, so there were 16 samples in total. The research was conducted at the Food Technology Laboratory, Department of Nutrition, Poltekkes, Ministry of Health, Makassar, and the sample was examined at the Quality Control Laboratory of SMTI Makassar. The results showed that per 100 grams of various Cokibuses, the average carbohydrate content decreased $-0.1 \%$, protein content increased between $0.21 \%$ to $0.72 \%$, fat increased $0.02 \%$ to $0.12 \%$, iron increased between $0.43 \%$ to $0.63 \%$. Calcium also increased between $0.29 \%$ to $0.85 \%$. The snack with the highest increase in nutritional content was Charrot muffins, and the lowest increase in nutritional value was Chobus cupcakes.

Kudapan merupakan makanan kecil yang biasa dihidangkan bersama minuman, baik untuk keperluan sehari-hari maupun untuk kesempatan khusus. Kudapan cokibus merupakan kudapan yang dibuat untuk dapat melengkapi asupan zat gizi, khususnya bagi anak yang mengalami stunting. Kota Makassar memiliki jumlah anak kekurangan gizi lebih tinggi dibandingkan kota/kabupaten lainnya, yaitu underweight $22,1 \%$, stunting $25,2 \%$ dan wasting 9,4\%. Penelitian ini bertujuan untuk mengetahui perubahan mutu gizi yakni kadar zat gizi makro, zat besi dan kalsium aneka kudapan cokibus. Jenis penelitian ini adalah penelitian laboratorik. Sampel terdiri dari 4 macam kudapan, 1 macam cokibus terdiri dari standar dan 1 perlakuan substitusi $10 \%$ tepung ikan gabus, dengan masing-masing sampel dua kali pengulangan, sehingga total ada 16 sampel. Penelitian dilakukan di Laboratorium Teknologi Pangan Jurusan Gizi Poltekkes Kemenkes Makassar dan pemeriksaan sampel di Laboratorium Quality Control SMTI Makassar. Hasil penelitian menunjukkan dalam per 100 gram aneka cokibus, rata-rata kadar karbohidrat menurun $-0,1 \%$, kadar protein meningkat antara $0,21 \%$ sampai $0,72 \%$, lemak meningkat $0,02 \%$ sampai $0,12 \%$, zat besi meningkat antara $0,43 \%$ sampai $0,63 \%$ dan kalsium juga meningkat antara $0,29 \%$ sampai $0,85 \%$. Kudapan yang paling tinggi nilai kadar gizi adalah muffin charrot dan yang paling rendah peningkatan kadar gizinya adalah chobus cupcake.
\end{abstract}

Corresponding Author:

Thresia Dewi Kartini B

Jurusan Gizi Poltekkes Kemenkes Makassar

Telp. 081242054419

Email: thresiadewikartini@poltekkes-mks.ac.id

\section{PENDAHULUAN}

Kudapan merupakan makanan ringan yang sangat banyak variasinya. Seiring dengan kemajuan informasi semakin banyak juga variasi ragam kudapan baik yang bernuansa tradisional, maupun nasional dan bahkan internasional (Purnomowati, Ida, dkk, 2012). Kudapan adalah makanan kecil yang biasa dihidangkan bersama minuman, baik untuk keperluan sehari-hari maupun untuk kesempatan khusus (Priyanti, 2018). Kudapan dijadikan selingan ketika seseorang melakukan aktivitasnya. Kudapan memiliki banyak variasi dengan kandungan zat gizi yang juga beragam. Namun sampai saat ini, sebagian besar kudapan lebih banyak mengandung karbohidrat. Kudapan bergizi bisa menjadi pilihan yang baik untuk memenuhi kebutuhan gizi dan berfungsi 
sebagai pelengkap asupan gizi dari makanan yang kita makan.

Kudapan cokibus merupakan kudapan yang dibuat untuk dapat melengkapi asupan zat gizi khususnya bagi anak yang mengalami stunting. Mutu dari suatu produk kudapan dapat dinilai dari kandungan zat gizi, keamanan pangan dan penerimaan di masyarakat. Produk kudapan yang sudah ada dapat ditingkatkan nilai gizinya dengan cara menyubstitusi dengan bahan pangan lain yang memiliki nilai zat gizi lebih bermanfaat untuk mengatasi masalah gizi yakni stunting (Nadimin, Nurjaya, 2017).

Prevalensi balita kekurangan gizi di Sulawesi Selatan masih tinggi dibandingkan dengan angka nasional dengan jumlah balita yang mengalami underweight sebesar $23 \%$, wasting sebanyak $10 \%$ dan stunting sebanyak 35,6\% (Kemenkes RI, 2018). Kota Makassar ternyata menjadi daerah yang memiliki jumlah anak yang menderita kekurangan gizi lebih tinggi dibanding kota/kabupaten lainnya, yaitu underweight $22,1 \%$, stunting $25,2 \%$ dan wasting 9,4\% (Kemenkes RI, 2017). Data tersebut menunjukkan bahwa perlu dilakukan upaya peningkatan asupan zat gizi anak balita dapat dilakukan melalui pemberian makanan makan tambahan.

Hasil-hasil studi menunjukkan bahwa intervensi pemberian makanan tambahan berupa jajanan lokal yang disubstitusi bahan ikan dapat meningkatkan status gizi pada anak balita (Nadimin et al., 2018). Hasil penelitian lain melaporkan bahwa pemberian makanan tambahan berupa biskuit dan bolu tepung tempe selama 30 hari dapat meningkatkan berat badan dan tinggi badan anak balita (Oktovina et al., 2015). Pemberian makanan tambahan dari jajanan lokal yang diperkaya zat gizi dengan tepung kerang terbukti dapat meningkatkan nilai Z-skor tinggi badan menurut umur pada anak balita stunting (Nadimin, Nurjaya, 2017).

Uraian inilah membuat peneliti tertarik untuk membuat produk cokibus yang disubstitusi tepung ikan gabus pada jajanan lokal yang sudah dikenal masyarakat, sebagai salah satu bentuk kudapan yang baru dengan nilai gizi yang lebih baik dibandingkan jajanan lokal yang sudah ada. Cokibus ini berupa banabus cake, chobus cupcake, muffin charrot dan dochapota. Tujuan dari penelitian ini adalah mengetahui perubahan mutu gizi aneka kudapan cokibus.

\section{METODE PENELITIAN \\ Jenis Penelitian}

Jenis penelitian yang digunakan adalah penelitian laboratorik (Arikunto, 2010).

\section{Lokasi dan Waktu Penelitian}

Penelitian ini berlokasi di Laboratorium Teknologi Pangan Poltekkes Kemenkes Makassar dan Laboratorium Quality Control SMTI Makassar. Penelitian dilaksanakan pada bulan Juli - Oktober 2019.

\section{Sampel}

Sampel terdiri dari 4 macam kudapan cokibus, 1 macam cokibus terdiri dari standar dan 1 perlakuan substitusi 10\% tepung ikan gabus, dan dilakukan 2 kali pengulangan, sehingga total ada 16 sampel.

\section{Alat dan Bahan}

Bahan-bahan yang digunakan dalam pembuatan aneka cokibus, seperti pada tabel 1 . Bahan tepung ikan gabus $10 \%$ dihitung berdasarkan berat tepung terigu pada setiap kudapan cokibus.

Adapun alat yang digunakan dalam proses pengolahan kudapan cokibus yaitu kompor gas, oven, grinder, ayakan 60 mesh, panci, timbangan analitik, sendok, sendok kayu, baskom, mixer, freezer, gelas ukur, pisau, talenan, piring, loyang, mangkok, hand gloves, gelas ukur, kertas kue dan kuas kue.

\section{Prosedur Penelitian}

Pembuatan tepung ikan gabus dengan cara ikan gabus segar disiangi dan dicuci di air mengalir, dipotong-potong dan diberi perasan air jeruk nipis. Selanjutnya potongan ikan dikukus selama 30 menit dengan air kukusan diberi serai dan lengkuas. Setelah itu, daging ikan gabus dipisahkan dari kulit dan tulang, dikeringkan dalam oven suhu $60^{\circ} \mathrm{C}$ selama 8 jam. Daging ikan yang sudah kering dihaluskan dengan grinder dan diayak dengan ayakan 60 mesh.

Pembuatan masing-masing cokibus dilakukan sesuai dengan bahan yang digunakan dan untuk proses pemasakannya dilakukan pengukusan untuk banabus cake, pemanggangan untuk chobus cupcake dan muffin charrot serta penggorengan untuk dochapota. Analisis karbohidrat dengan luff schrool, protein dengan micro kjedahl, lemak dengan soxhlet, zat besi dengan 
spektrofotometri dan kalsium dengan molumetri.

Data dari hasil analisis sampel cokibus dianalisis secara deskriptif. Rekomendasi Etik penelitian dengan nomor 1126/KEPKPTKMKS/X/2019, tanggal 4 Oktober 2019 yang diperolehkan dari Komisi Etik Poltekkes Kemenkes Makassar.

\section{Tabel 1. Bahan Aneka Kudapan Cokibus}

\begin{tabular}{lcccc}
\hline \multicolumn{1}{c}{ Bahan } & Banabus Cake & Chobus Cupcake & Muffin Charrot & Dochapota \\
\hline Tepung terigu (g) & 180 & 76 & 225 & 450 \\
Gula pasir (g) & 150 & 100 & 200 & 25 \\
Telur ayam (btr) & 4 & 3 & 4 & 1 \\
Minyak goreng (ml) & 175 & - & - & - \\
Margarine (g) & - & 125 & 200 & 50 \\
Coklat bubuk (g) & - & 20 & - & - \\
Susu bubuk (g) & - & 10 & - & - \\
Susu cair (ml) & - & - & - & 250 \\
Fermipan (g) & - & - & - & 7 \\
Pisang ambon (g) & 100 & - & - & - \\
Wortel (g) & - & - & 350 & - \\
Kentang (g) & - & - & - & 125 \\
Baking powder (sdt) & 1 & - & $1 / 2$ & - \\
Soda kue (sdt) & $1 / 2$ & - & $1 / 2$ & - \\
Kayu manis (sdt) & $1 / 2$ & - & - & - \\
Garam (g) & 3 & - & - & \\
SP (sdt) & - & 1 & 25 & 50 \\
Tepung ikan gabus (g) & 20 & 14 & & \\
\hline
\end{tabular}

\section{HASIL PENELITIAN}

Hasil analisis kadar gizi cokibus per 100 gram masing-masing produk menunjukkan bahwa kadar zat gizi tertinggi pada masingmasing cokibus, yakni muffin charrot memiliki peningkatan kadar kalsium sebesar 3,05mg, banabus cake memiliki peningkatan kadar lemak sebesar $1,62 \mathrm{~g}$ dan zat besi $0,40 \mathrm{mg}$, dochapota peningkatan kadar protein sebesar $1,96 \mathrm{~g}$, dan chobus cupcake yang memiliki peningkatan kadar zat gizi lebih rendah dibanding cokibus lainnya, seperti pada tabel 2 .

Tabel 2. Hasil Analisis Kadar Zat Gizi Aneka Kudapan Cokibus per 100 gram

\begin{tabular}{lccccc}
\hline $\begin{array}{c}\text { Aneka Kudapan } \\
\text { Cokibus }\end{array}$ & $\begin{array}{c}\text { Karbohidrat } \\
(\text { gram) }\end{array}$ & $\begin{array}{c}\text { Protein } \\
(\text { gram) }\end{array}$ & $\begin{array}{c}\text { Lemak } \\
\text { (gram) }\end{array}$ & $\begin{array}{c}\text { Zat Besi } \\
(\mathbf{m g})\end{array}$ & $\begin{array}{c}\text { Kalsium } \\
(\mathbf{m g})\end{array}$ \\
\hline Banabus Cake Ori & 21.10 & 2.87 & 16.23 & 0.90 & 0.70 \\
Banabus Cake & 20.91 & 4.30 & 17.85 & 1.30 & 0.90 \\
Chobus Cupcake Ori & 21.09 & 4.43 & 14.26 & 1.30 & 1.60 \\
Chobus Cupcake & 20.79 & 5.34 & 14.50 & 1.90 & 2.55 \\
Muffin Charrot Ori & 21.07 & 2.46 & 13.09 & 0.40 & 3.60 \\
Muffin Charrot & 20.94 & 4.24 & 14.64 & 0.65 & 6.65 \\
Dochapota Ori & 21.15 & 4.72 & 17.14 & 0.70 & 2.05 \\
Dochapota & 21.04 & 6.67 & 18.33 & 1.00 & 3.10 \\
\hline
\end{tabular}

Tabel 3 menunjukkan bahwa secara umum ada perubahan kadar zat gizi pada masing-masing cokibus. Perubahan tersebut ada penurunan dan peningkatan. Kadar karbohidrat rata-rata mengalami penurunan sebesar $-0,1 \%$. Berbeda dengan kadar protein dan kalsium yang meningkat masing-masing antara $0,21 \%$ sampai $0,72 \%$ dan antara $0,29 \%$ sampai $0,85 \%$. Peningkatan tertinggi secara berurutan pada kadar kalsium, protein dan zat besi. Kudapan yang paling tinggi mengalami peningkatan kadar gizi adalah muffin charrot dan yang 
paling rendah peningkatan kadar gizinya adalah

chobus cupcake.

Tabel 3. Persentase Perubahan Kadar Zat Gizi Aneka Kudapan Cokibus

\begin{tabular}{lccccc}
\hline $\begin{array}{c}\text { Aneka Kudapan } \\
\text { Cokibus }\end{array}$ & $\begin{array}{c}\text { Karbohidrat } \\
(\boldsymbol{\%})\end{array}$ & $\begin{array}{c}\text { Protein } \\
(\boldsymbol{\%})\end{array}$ & $\begin{array}{c}\text { Lemak } \\
(\boldsymbol{\%})\end{array}$ & $\begin{array}{c}\text { Zat Besi } \\
(\boldsymbol{\%})\end{array}$ & $\begin{array}{c}\text { Kalsium } \\
(\boldsymbol{\%})\end{array}$ \\
\hline Banabus Cake & -0.01 & 0.50 & 0.10 & 0.44 & 0.29 \\
Chobus Cupcake & -0.01 & 0.21 & 0.02 & 0.46 & 0.59 \\
Muffin Charrot & -0.01 & 0.72 & 0.12 & 0.63 & 0.85 \\
Dochapota & -0.01 & 0.41 & 0.07 & 0.43 & 0.51 \\
\hline
\end{tabular}

\section{PEMBAHASAN}

Mutu gizi kudapan cokibus rata-rata memiliki kadar karbohidrat yang lebih rendah dibandingkan dengan kudapan tanpa substitusi tepung ikan gabus. Hal ini disebabkan oleh adanya sejumlah tepung ikan gabus yang disubstitusikan ke dalam adonan masingmasing kudapan. Sebagaimana diketahui bahwa $100 \mathrm{~g}$ tepung terigu menyumbangkan karbohidrat sebesar 77,2g dan pada ikan gabus dan tepungnya tidak terkandung karbohidrat (Astawan, 2009). Hal inilah yang juga menyebabkan kadar karbohidrat pada aneka kudapan menurun kadar gizinya, meski hanya 0,1\%. Hasil penelitian Kusharto Clara M, et.al. (2015), juga menunjukkan hasil yang sama untuk kadar karbohidrat yang menurun dibandingkan dengan kontrol pada tiga jenis kudapan yaitu bolu rampah, deppatory dan stick pury. Sebaliknya penelitian Melsa Nilmalasari dan Esthy Rahman Asih (2017) menunjukkan kadar karbohidrat kue kering sagu dengan substitusi tepung ikan patin pada empat perlakuan berkisar antara 72,50\%-82,68\% dan ini sudah sesuai persyaratan mutu cookies SNI 01-2973-1992 dimana kadar karbohidrat minimal ditetapkan adalah $70 \%$. Hal ini dikarenakan sumber karbohidrat pada kue kering berasal dari tepung sagu dan gula halus.

Penelitian ini menggunakan tepung terigu dan bahan lainnya digantikan dengan $10 \%$ tepung ikan gabus dari jumlah tepung terigu pada masing-masing kudapan. Penelitian Ramadhan, Nuryanto and Wijayanti (2019), menyebutkan bahwa cookies yang mendekati standar permenkes dan daya terimanya baik yaitu F1 dengan substitusi tepung ikan teri sebanyak $10 \%$. Penelitian ini menggunakan tepung ikan gabus yang diproses dengan cara ikan gabus dikukus menggunakan berbagai rempah, sehingga daging ikan gabus berkurang aroma amisnya. Setelah itu dikeringkan dengan oven dan dihaluskan menjadi tepung ikan gabus yang disubstitusikan ke adonan kudapan. Selain itu, aneka kudapan cokibus menggunakan bahan-bahan seperti coklat, pisang ambon, kentang dan wortel yang dapat menyamarkan bau dari tepung ikan gabus. Penelitian ini berbeda dengan hasil penelitian Nadimin, Nurjaya dan Retno Sri Lestari (2018), yang menyatakan konsentrasi tepung ikan gabus yang terbaik untuk pembuatan jajanan lokal adalah 5\%. Jajanan lokal yang dimaksud adalah bolu, bangke sagu, bangke kelapa dan putri salju.

Hasil penelitian menunjukkan peningkatan kadar zat gizi pada aneka kudapan cokibus, khususnya kadar protein, lemak, zat besi dan kalsium. Protein, zat besi dan kalsium merupakan zat gizi penting untuk pertumbuhan linier. Zat gizi ini banyak terdapat pada sumber pangan hewani, seperti ikan gabus. Peningkatan kadar protein dalam penelitian ini disebabkan kadar protein pada ikan gabus lebih tinggi dari bahan pangan lain yang dikenal sebagai sumber protein seperti telur, daging ayam maupun daging sapi. Kadar protein per $100 \mathrm{~g}$ ikan gabus adalah 20,0g dan lebih tinggi dibandingkan telur sebesar $12,8 \mathrm{~g}$, daging ayam sebesar 18,2g serta daging sapi sebesar 18,8g. Selain itu nilai cerna ikan sangat baik, yaitu mencapai lebih dari 90\% (Astawan, 2009). Sebaliknya pada penelitian pengaruh substitusi tepung ikan teri dan tepung kacang merah pada pie mini terjadi penurunan kadar protein hasil analisis laboratorium, dibandingkan dengan hasil perhitungan menggunakan DKBM pada konsentrasi substitusi tertinggi. Hal ini disebabkan oleh adanya pemanasan dengan suhu tinggi pada pembuatan pie mini, yang menyebabkan protein mengalami denaturasi (Faroj, 2019).

Sejalan dengan penelitian Ramadhan, Nuryanto and Wijayanti (2019), menunjukkan bahwa semakin tinggi substitusi tepung ikan teri, maka semakin tinggi pula kandungan 
protein, lemak, kadar air, kadar abu, kalsium dan besi dan semakin rendahnya karbohidrat pada cookies. Hasil penelitian lain juga menunjukkan bahwa proporsi tepung terigu, tepung ikan haruan, tepung biji dan buah labu kuning terbukti memiliki pengaruh yang signifikan terhadap biskuit dengan kadar seng $\mathrm{p}=0,008$ dan zat besi $\mathrm{p}=0,001$ (Roifah et al., 2019). Selain itu, kadar zat besi juga meningkat pada penelitian serabi yang diperkaya tepung ikan teri dan tepung tempe dengan konsentrasi 10\%:5\% (Fanny et al., 2019). Peningkatan kadar kalsium juga terdapat pada hasil penelitian lain yang sejalan yaitu meningkatkan kadar kalsium pada kastengel seiring dengan semakin banyaknya tepung bandeng presto yang disubstitusikan pada kastangel (Putri \& Kasih, 2020).

Peningkatan kadar protein, lemak, zat besi dan kalsium pada aneka kudapan cokibus terjadi karena adanya substitusi tepung ikan gabus yang merupakan sumber zat gizi protein, zat besi dan kalsium. Hasil penelitian ini banyak sejalan dengan penelitian lain yang menggunakan sumber hewani dalam mengembangkan atau memperkaya produk yang sudah ada. Produk-produk kudapan ini diperuntukkan bagi penanganan masalah gizi secara preventif di tingkat masyarakat.

Kudapan cokibus ini memiliki mutu gizi yang lebih tinggi dibandingkan dengan kudapan tanpa substitusi tepung ikan gabus, kecuali untuk kadar karbohidrat dan ini merupakan salah satu kelemahan dari penelitian ini. Selain itu, kudapan Chobus Cupcake ternyata memiliki peningkatan kadar zat gizi yang paling rendah dibanding cokibus lainnya, sehingga perlu dilanjutkan untuk diteliti lagi. Aneka cokibus ini memiliki peningkatan kadar protein yang paling tinggi dibandingkan dengan lemak, zat besi dan kalsium. Oleh sebab itu aneka kudapan cokibus ini dapat digunakan sebagai salah satu alternatif produk untuk pemberian makanan tambahan khususnya bagi anak balita yang kurang gizi.

\section{KESIMPULAN DAN SARAN}

Aneka kudapan cokibus menghasilkan kudapan yang memiliki peningkatan kadar mutu gizi. Kudapan yang paling tinggi peningkatan kadar zat gizinya adalah muffin charrot.

Disarankan untuk dapat menganalisis keamanan pangan dari produk kudapan cokibus ini, sehingga kudapan cokibus ini dapat digunakan untuk mengatasi masalah gizi lainnya.

\section{DAFTAR PUSTAKA}

Arikunto, S. (2010). Prosedur Penelitian Suatu Pendekatan Praktik (Revisi). PT Rineka Cipta.

Astawan, M. (2009). Panduan Karbohidrat Terlengkap. Jakarta: PT Gramedia Pustaka.

Clara M Kusharto, Trina Astuti, Aisyah, Sri Anna Marliyati, Rosmiati, R. (2015). Formulasi, Kandungan Gizi, dan Daya Terima Kue-Kue Tradisional Makassar Berbasis Tepung Pupae-Mulberry (Pury) sebagai Makanan Bergizi Masa Depan. Jurnal Gizi dan Pangan, 10(3), pp. 197206. doi: 10.25182/jgp.2015.10.3.

Fanny, L. et al. (2019). Daya Terima dan Kandungan Zat Gizi Mikro Serabi yang Diperkaya Tepung Tempe dan Tepung Ikan Teri (Stolephorus sp). Media Gizi Pangan, 26(2), pp. 190-200.

Faroj, M. N. (2019). Pengaruh Substitusi Tepung Ikan Teri (Stolephorus commersonii) dan Tepung Kacang Merah (Vigna Angularis) terhadap Daya Terima dan Kandungan Protein Pie Mini. Media Gizi Indonesia, 14(1), pp. 56-65.

Kemenkes RI. (2017). Buku Saku Pemantauan Status Gizi. Buku Saku, pp. 1-150.

Kemenkes RI. (2018). Hasil Riset Kesehatan Dasar Tahun 2018. Kementrian Kesehatan RI, 53(9), pp. 1689-1699.

Melsa Nilmalasari, dan Esthy Rahman Asih. (2017). Daya Terima Kue Kering Sagu Dengan Substitusi Tepung Ikan Patin (Pangasius hypopthalmus). Jurnal Proteksi Kesehatan, 6(1), pp. 52-63.

Nadimin, Nurjaya, and Sitti Sahariah R. (2017). The Effect of Local Snacks Enriched with Shell Flour on The Nutritional Status of Stunting Children. Dama International Journal of Researchers (DIJR), 2(7), pp. 57-62.

Nadimin, N., Nurjaya, N. and Lestari, R. S. (2018). Daya terima terhadap jajanan lokal Sulawesi Selatan subtitusi tepung ikan gabus (Channa striata). AcTion: Aceh Nutrition Journal, 3(2), p. 141. doi: 10.30867/action.v3i2.115.

Oktovina, R., Bambang, W. and Merryana, A. (2015). Pengaruh Pemberian Makanan 
Tambahan Biskuit dan Bolu Tepung Tempe terhadap Peningkatan Berat Badan dan Tinggi Badan pada Balita Gizi Kurang Tahun 20I5. Jurnal Ilmiah Kedokteran. Fakultas Kedokteran Universitas Wijaya Kusuma Surabaya, 4(1), pp. 16-24.

Priyanti, E. (2018). Kudapan dan Makanan Indonesia, pp. 1-4.

Purnomowati, Ida, D. H. dan C. S. (2012). Aneka Kudapan Berbahan Ikan. Yogyakarta: Kanisisus.

Putri, M. F. and Kasih, C. A. (2020). Jajanan Sehat dan Kaya Kalsium untuk Keluarga : Subtitusi Tepung Bandeng Presto sebagai Bahan Kastangel. JKKP: Jurnal Kesejahteraan Keluarga dan Pendidikan, 7(April), pp. 98-106.
Ramadhan, R., Nuryanto, N. and Wijayanti, H. S. (2019). Kandungan Gizi dan Daya Terima Cookies Berbasis Tepung Ikan Teri (Stolephorus Sp) sebagai PMT-P untuk Balita Gizi Kurang. Journal of Nutrition College, 8(4), pp. 264-273. doi: 10.14710/jnc.v8i4.25840.

Roifah, M., Razak, M. and Suwita, I. K. (2019). Subtitusi tepung kacang hijau (Vigna radiata) dan Tepung Ikan Tuna (Thunnus sp.) sebagai Biskuit PMT Ibu Hamil Terhadap Kadar Proksimat, Nilai Energi, Kadar Zat Besi, dan Mutu Organoleptik. Teknologi Pangan: Media Informasi dan Komunikasi Ilmiah Teknologi Pertanian, 10(2), pp. 128-138. doi: 10.35891/tp.v10i2.1662. 